https://www.journal-imab-bg.org

Original article

\title{
VITAMIN D LEVELS IN PATIENTS WITH CHRONIC HEPATITIS B, CHRONIC HEPATITIS C, AND HEALTH CONTROLS
}

\author{
Biljana Ilkovska ${ }^{1}$, Bisera K. Trifunova ${ }^{2}$, Sandra Hristovska ${ }^{1}$, Marina Ivanovska $^{1}$ \\ 1) Department of laboratory diagnostics, PHO Clinical hospital dr Trifun \\ Panovski, Bitola, Macedonia. \\ 2) Department of dermatology and venereology, Acibaden city clinic Tokuda \\ hospital Sofia, Bulgaria.
}

\begin{abstract}
Purpose: Hepatitis B virus and Hepatitis C virus infection are the most common cause of acute and chronic hepatitis. Over the past decade, numerous studies reported that patients with chronic liver disease, especially HCVpositive and HBV-positive patients, have decreased $25(\mathrm{OH}) \mathrm{D}$ levels compared to healthy people.

The aim of the present study has been to establish the incidence and severity of Vitamin D deficiency in a cohort of Macedonian patients with chronic hepatitis B and $\mathrm{C}$ and health controls.

Material/Methods: This pilot study was performed in Clinical hospital in Bitola (R. Macedonia). The total number of participants was 148, 103 of them were healthy people, 23 were chronic hepatitis $\mathrm{C}$, and 22 were chronic hepatitis B patients. The serum was separated, and Vitamin D levels, HBsAg and Anti HCV titers were measured by using Abbot Architect platform.

Results: We established that the Macedonian population suffers from a deficiency of vitamin D. Vitamin D levels are lower in healthy women, and women with hepatitis $\mathrm{B}$ and $\mathrm{C}$ compared with males. We found that Vitamin $\mathrm{D}$ is significantly lower in patients with hepatitis B compared to control group, but there is not a significant correlation between this two groups, and we can clearly state that HBV- infected patients are at high risk of Vitamin D deficiency.

Conclusions: We confirmed that only $12 \%$ of all examinated subjects $(n=145)$ had values of vitamin $D$ within normal limits. This indicates the need to consume foods rich in Vitamin D, require higher sun exposure or vitamin D supplementation should be recommended in healthy people, patients with chronic hepatitis $\mathrm{C}$ and $\mathrm{B}$.
\end{abstract}

Keywords: hepatitis B virus, hepatitis C vitus, vitamin D, health controls,

\section{INTRODUCTION}

Hepatitis B virus and Hepatitis $\mathrm{C}$ virus infection are the most common cause of acute and chronic hepatitis, cirrhosis and hepatocellular carcinoma worldwide. To date, more than two billion individuals have been infected, of which 350 million are chronic carriers of the virus B [1], and viral hepatitis $\mathrm{C}$ infects infect more than 130 million individuals [2].

Over the past decade, numerous studies reported that patients with chronic liver disease, especially HCV-positive and HBV-positive patients, have decreased 25(OH)D levels compared to healthy people [1].

Vitamin D is a group of fat-soluble prohormones which were identified after the discovery of the anti-rachitic effect of cod liver oil in the early part of the 20th century. The two major biologically inert precursors of Vitamin D are Vitamin D3 (cholecalciferol) and Vitamin D2 (ergocalciferol). Vitamin D3 is formed when 7-dehydrocholesterol in the skin is exposed to solar ultraviolet B (UVB, 290$320 \mathrm{~nm}$ ), and then converted to previtamin D3. In a heatdependent process, previtamin D3 is immediately converted to Vitamin D. Excess UVB rays transform previtamin D3 in to biologically inactive metabolites, tachysterol and lumisterol. Vitamin D2 is plant derived, produced exogenously by irradiation of ergosterol, and enters the circulation through diet.

Both Vitamin D precursors resulting from exposure to the sunlight and the diet are converted to 25-hydroxyvitamin D [25(OH)D] (calcidiol) when they enter the liver. $25(\mathrm{OH}) \mathrm{D}$ is the major circulating form of Vitamin D and is used to determine Vitamin D status. In order to be biologically active, additional hydroxylation in the kidneys is needed to form active 1,25-dihydroxyVitamin D [1,25(OH)2D] (calcitriol) [3]. The main effects of Vitamin $\mathrm{D}$ are mediated by the Vitamin $\mathrm{D}$ receptor, which is widely distributed throughout the body, including in the brain, immune cells, bone, pancreas, and muscle. The canonical functions of Vitamin D are to increase calcium absorption and to maintain healthy bones. Active Vitamin D operates in conjunction with several other hormones, including parathyroid hormone. When the serum levels of ionized calcium are low, parathyroid hormone levels increase. Parathy- 
roid hormone stimulates bone resorption, causing the release of calcium. This release of calcium from the skeleton maintains serum calcium levels within a narrow physiological range but can lead to bone loss and fracture if allowed to continue unabated. Vitamin D levels are considered to be adequate when parathyroid hormone levels are maximally suppressed. Vitamin D deficiency is generally associated with parathyroid hormone elevations [4].

Therefore, the stable, easy to quantify metabolite, $25(\mathrm{OH}) \mathrm{D} 3$, is usually measured in clinical routine to assess a patient's Vitamin D status [5]. Vitamin D has not only important functions in the metabolism of calcium and bone homeostasis but also manifold effects in the fine regulation of immune responses [2]. Vitamin D is a key immune modulator. It reduces levels of pro-inflammatory cytokines and inflammation and enhances adaptive and innate immune responses. Vitamin D supplements increase muscle strength, and they are reported to reduce depression and fatigue, although improvements have not been observed in all studies. Among dialysis patients, Vitamin D supplements reduce the need for erythropoiesis stimulating agents [4]. There is increasing evidence of Vitamin D deficiency effects on a wide spectrum of diseases, including osteoporosis, autoimmunity, asthma, infectious diseases, several forms of malignancy and even psychiatric disorders [2]. According to World Health Organization (WHO) recommendations, $25(\mathrm{OH}) \mathrm{D}$ (the main circulation form of Vitamin D) levels of ( $\geq 14$ and $<30 \mathrm{ng} / \mathrm{mL}$ ) and $<14 \mathrm{ng} / \mathrm{mL}$ are defined as Vitamin D insufficiency and Vitamin D deficiency, respectively [1].

The aim of the present study has been to establish the incidence and severity of Vitamin D deficiency in a cohort of Macedonian patients with chronic hepatitis B and $\mathrm{C}$ and health controls.

\section{METHODS}

This pilot study was performed from April 2018 to September 2018 at the Department of medical biochemistry of Public Health Organization Clinical hospital Dr Trifun Panovski in Bitola (R. Macedonia). The total number of participants was 148,103 of them were healthy people from Bitola, R.Macedonia, 23 were chronic hepatitis $\mathrm{C}$, and 22 were chronic hepatitis B patients. The blood samples were taken between $8 \mathrm{AM}$ and $10 \mathrm{AM}$; after an overnight overnight fast (12 hours). All participants gave written informed consent for participation in the study.

\section{Laboratory methods}

The serum was separated, and Vitamin D levels were measured by using fully automated immunoassay for 25hydroxy Vitamin D on the Abbot Architect platform. The assay is a 1-step delayed chemiluminescent microparticle immunoassay (CMIA) with an automated online pretreatment step designed to allow Vitamin D assays into routine laboratory testing workflow. This method received FDA approval in 2011.

HBsAg and Anti HCV titers were determined with the Abbot Architect assay based on an automated chemiluminescent microparticle immunoassay, following the manufacturer's recommendation.

Liver function and other biochemical parameter tests, included assessment of alanine transaminase (ALT), aspartate transaminase (AST), alkaline phosphatase (ALP), lactate dehydrogenase (LDH or LD), gamma-glutamyl transferase (GGT), cholesterol, triglycerides, HDL- cholesterol, LDL- cholesterol, glucose, uric acid, total and direct bilirubin, albumin, were performed using Abbot Architect platform.

\section{Statistical methods}

Statistical analysis was performed with SPSS for Windows release 16.0.2, using the standard descriptive methods (mean $\pm \mathrm{SD}$ ), and corresponding analytical tests. Levene's Test for Equality of Variances was performed to determine the equality of variances, and appropriate independent samples, while the Student's t-test was used to compare the means. The correlation between the results was tested with Pearson's the Pearson's Correlation Coefficient. The data are presented as mean \pm standard deviation (SD), and $\mathrm{p}$ d" 0.05 is considered statistically significant.

\section{RESULTS}

This pilot study included 148 participants, 103 of them are healthy people, 23 are $\mathrm{CHC}$ and 22 are CHB patients.

Participants were divided in 3 groups:

- Health controls $(n=103)$ males $(n=39)$, females $(n=64)$

- Chronic hepatitis B $(n=22)$ males $(n=9))$, females $(n=13)$

- Chronic hepatitis C $(n=23)$ males $(n=20)$, females $(\mathrm{n}=3)$

Participants in group health controls were age 15 to 82 years, (mean 49,6), females were age 23 to 78 (mean 49), males were age 15 to 82 (mean 50,5).

Participants in the group with chronic hepatitis B were age 25 to 70 years, (mean 45,2), females were age 26 to 70 (mean 43,4), males were age 25 to 58 (mean 47,8). Participants in the group with chronic hepatitis $\mathrm{C}$ were age 20 to 62 years, (mean 33,3), females were age 33 to 62 (mean 52,3), males were age 20 to 41 (mean 30,45).

Following the recommendation of WHO we found that health controls $(n=103)$ of this study are with Vitamin $\mathrm{D}$ insufficiency. Levels of Vitamin D were ranged from 4.5 $\mathrm{ng} / \mathrm{mL}$ to $59.5 \mathrm{ng} / \mathrm{mL}$ (mean $19.1 \pm 10.12$ ). In female control group levels of Vitamin D was ranged from $4.5 \mathrm{ng} / \mathrm{mL}$ to $55.8 \mathrm{ng} / \mathrm{mL}$ (mean $18.37 \pm 10.69$ ), and in males control group level of Vitamin D was ranged from $5.5 \mathrm{ng} / \mathrm{mL}$ to $59.5 \mathrm{ng} / \mathrm{mL}$ (mean $20.3 \pm 9.13$ ). Thirty six (35\%) health people included in this study had Vitamin D deficiency (Vitamin D $<14 \mathrm{ng} / \mathrm{ml}), 56(54 \%)$ health controls had Vitamin D insufficiency (Vitamin D valuest are $\geq 14$ and $<30$ $\mathrm{ng} / \mathrm{mL})$ and $11(11 \%)$ examinees of control group had normal Vitamin D values (Vitamin D >30 ng/ml). 
Fig. 1. Present concentration of Vitamin D in health controls

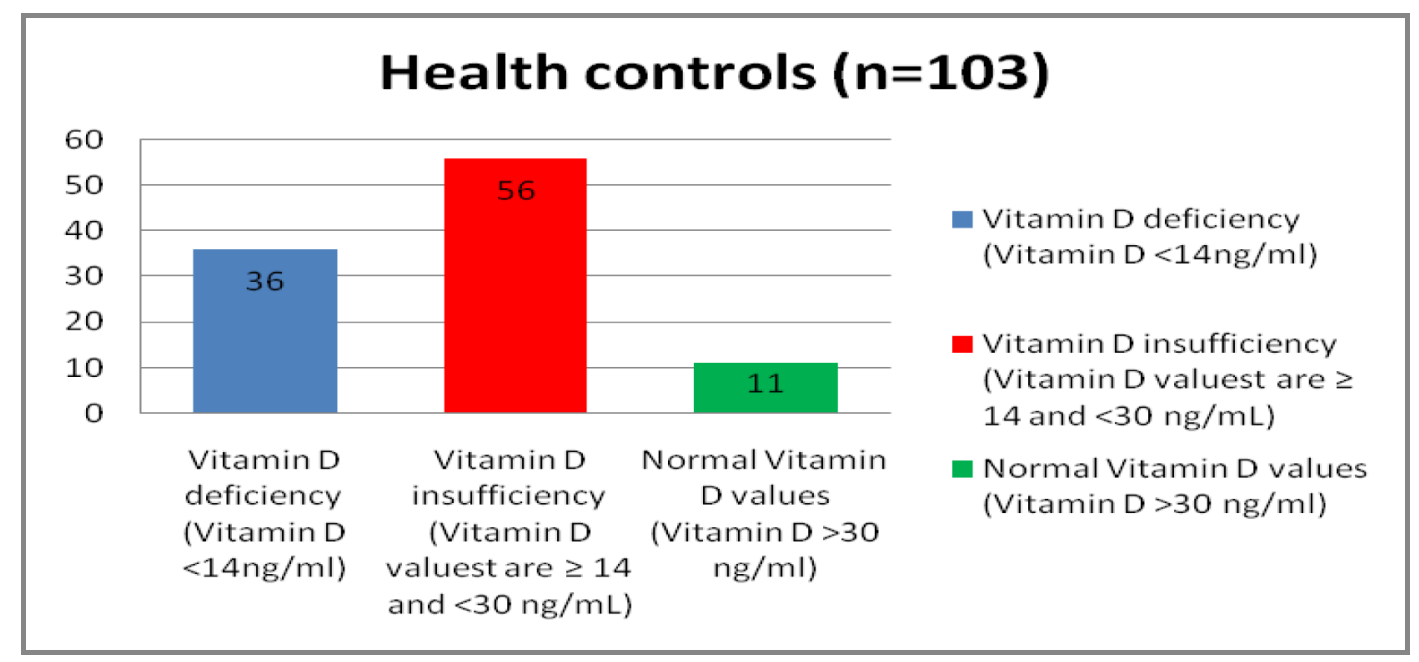

The concentration of Vitamin D in patients group with chronic hepatitis $\mathrm{C}$ is are the same like health controls, with Vitamin D insufficiency, and their range was from $3.9 \mathrm{ng} / \mathrm{mL}$ to $55.7 \mathrm{ng} / \mathrm{mL}$ (mean $21.9 \pm 13.43$ ). In females group with chronic hepatitis $\mathrm{C}$ was ranged from 10.3 $\mathrm{ng} / \mathrm{mL}$ to $23.1 \mathrm{ng} / \mathrm{mL}$ (mean $16.03 \pm 6.5$ ), and in males group with chronic hepatitis $\mathrm{C}$ was ranged from $3.9 \mathrm{ng} /$

$\mathrm{mL}$ to $55.7 \mathrm{ng} / \mathrm{mL}$ (mean $22.7 \pm 14.08$ ).

Seven $(30 \%)$ patients with chronic hepatitis $\mathrm{C}$ had Vitamin D deficiency ( Vitamin D $<14 \mathrm{ng} / \mathrm{ml}$ ), 11 (48\%) patients with chronic hepatitis $\mathrm{C}$ had Vitamin D insufficiency (Vitamin D valuest are $\geq 14$ and $<30 \mathrm{ng} / \mathrm{mL}$ ) and only 5 $(22 \%)$ patients are with normal Vitamin D values (Vitamin $\mathrm{D}>30 \mathrm{ng} / \mathrm{ml})$.

Fig. 2. Present concentration of Vitamin D in patients with chronic hepatitis $C$

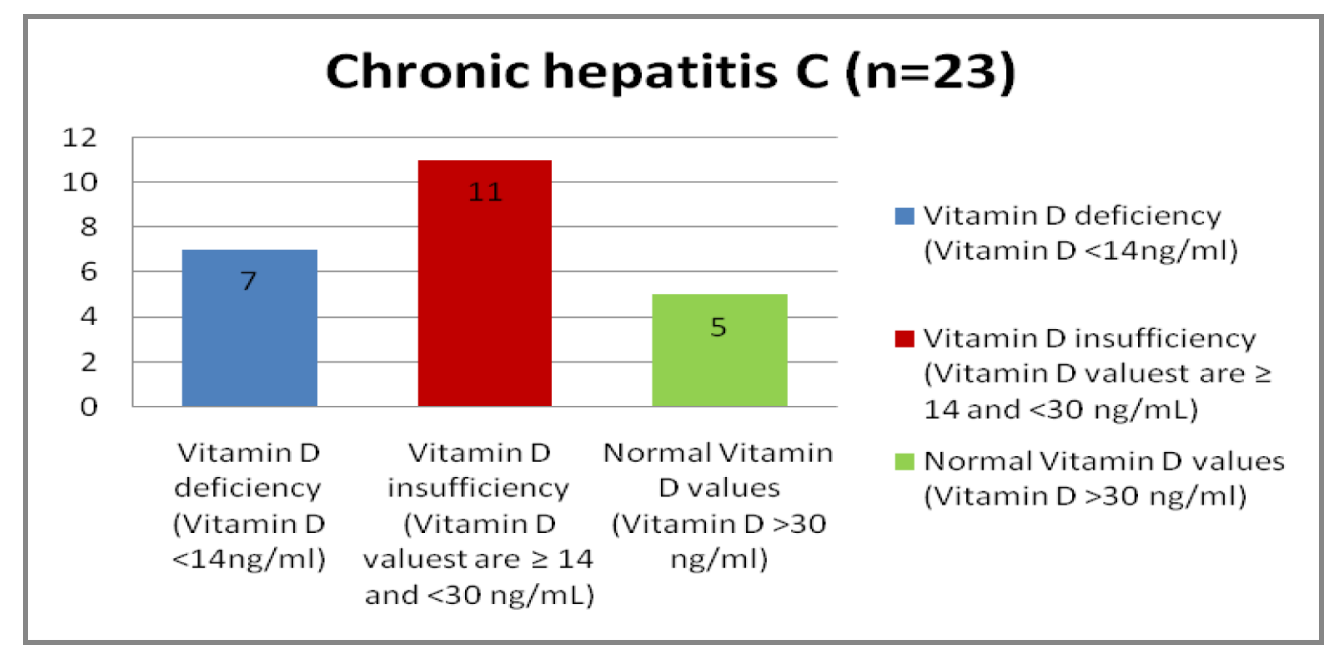

Patients group with chronic hepatitis B was in the border of Vitamin D deficiency, and their range of Vitamin D was from $4.8 \mathrm{ng} / \mathrm{mL}$ to $32.3 \mathrm{ng} / \mathrm{mL}$ (mean $14.8 \pm 8.1$ ). In females group with chronic hepatitis B we found Vitamin D deficiency with a range of Vitamin D from $5.4 \mathrm{ng} / \mathrm{mL}$ to $31.2 \mathrm{ng} / \mathrm{mL}$ (mean 13.56 \pm 7.8), and in males group with chronic hepatitis B we found Vitamin D insufficiency with range of Vitamin D from $4.8 \mathrm{ng} / \mathrm{mL}$ to $32.3 \mathrm{ng} / \mathrm{mL}$ (mean $16.7 \pm 8.56)$.
Eleven $(50 \%)$ patients with chronic hepatitis B had Vitamin D deficiency ( Vitamin D $<14 \mathrm{ng} / \mathrm{ml}$ ), 9 (41\%) patients with chronic hepatitis B had Vitamin D insufficiency (Vitamin D valuest are $\geq 14$ and $<30 \mathrm{ng} / \mathrm{mL}$ ) and only 2 (9\%) patients are with normal Vitamin D values (Vitamin D > $30 \mathrm{ng} / \mathrm{ml}$ ). 
Fig. 3. Present concentration of Vitamin D in patients with chronic hepatitis B

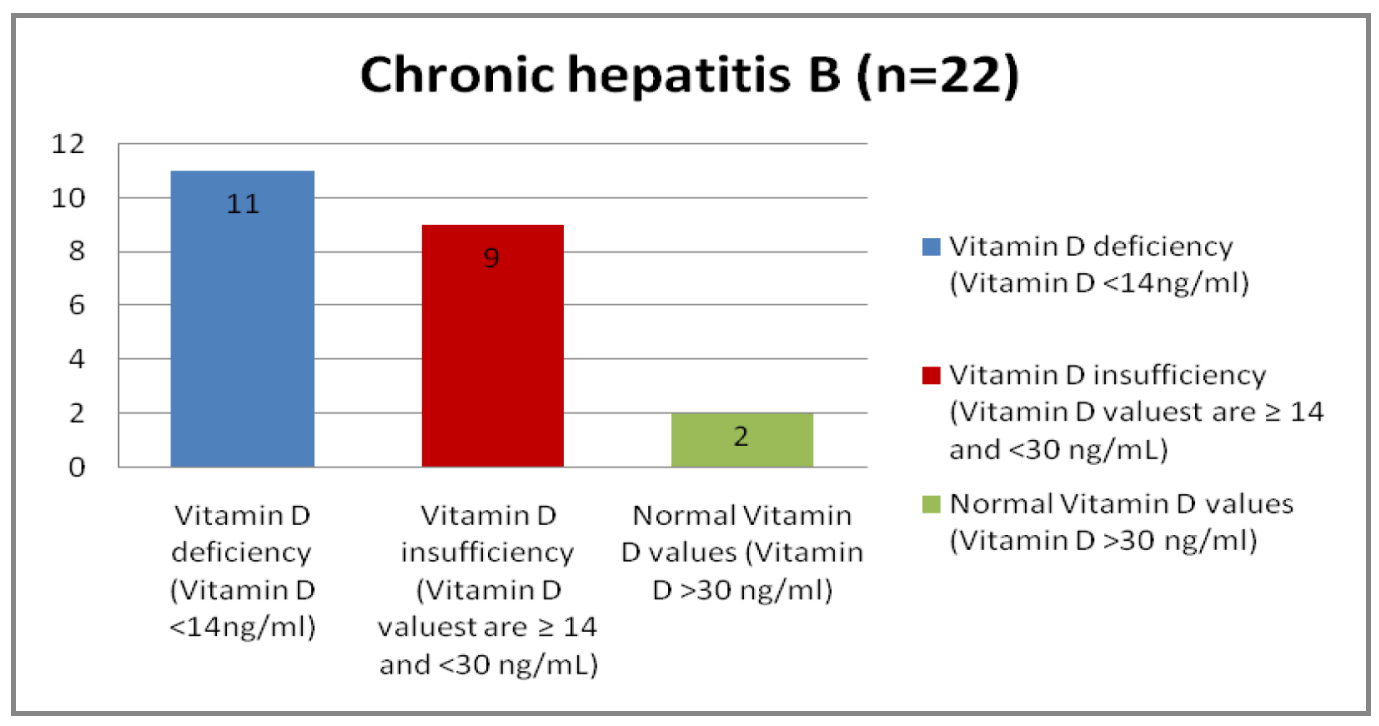

That means that only 7 patients with chronic hepatitis of all 45 examinees have normal Vitamin D serum concentration.

Statistical analysis showed that patients with chronic hepatitis C (mean $21.9 \pm 13.43$ ) had statistically higher Vitamin D levels than patients with chronic hepatitis B (mean $14.8 \pm 8.1$ ) with $\mathrm{p}=0,04$ (Correlation is significant at the 0.05 level).

In patients group with chronic hepatitis $\mathrm{C}$, we found increased levels of liver enzymes ALT, AST, ALP, LDH, GGT, compared with chronic hepatitis B patients. All enzymes levels that were analyzed in the research had significantly higher serum concentrations in a group chronic hepatitis $\mathrm{C}$ compared to the group of chronic hepatitis B. Values of the

enzyme ALT in the group with chronic hepatitis $\mathrm{C}$ have mean $210,43 \pm 559.75$, while in the group of chronic hepatitis B, ALT has mean $67,27 \pm 151,16$. Values of AST in the group with chronic hepatitis $C$ have mean $192,47 \pm 574$.43, while in the group of chronic hepatitis B, AST has mean 37,59 \pm 49,27 . Values of the enzyme ALP in the group with chronic hepatitis $C$ have mean $96,95 \pm 34.44$, while in the group of chronic hepatitis B, ALP has mean 82,18 \pm 33.65. Values of the enzyme $\mathrm{LDH}$ in the group with chronic hepatitis $\mathrm{C}$ have mean $351,26 \pm 483.98$ while in the group of chronic hepatitis B, LDH has mean $186,04 \pm 54.4$. Values of the enzyme GGT in the group with chronic hepatitis $\mathrm{C}$ have mean 77,60 \pm 80.32 while in the group of chronic hepatitis B, GGT has mean $27,54 \pm 36$

Table 1. Present mean values $\pm \mathrm{SD}$ of serum concentrations of: alanine transaminase (ALT), aspartate transaminase (AST), alkaline phosphatase (ALP), lactate dehydrogenase (LDH or LD), gamma-glutamyl transferase (GGT), cholesterol, triglycerides, HDL- cholesterol, LDL- cholesterol, glucose, uric acid, total and direct bilirubin, albumincholesterol, HDL-cholesterol, LDL-cholesterol,triglycerides, haemoglobin and platelates in patientrs with chronic hepatitis $\mathrm{C}$ and $\mathrm{B}$.

\begin{tabular}{|l|c|c|}
\hline Variables & $\begin{array}{c}\text { Chronic hepatitis B } \\
\text { patients }(\mathrm{n}=22)\end{array}$ & $\begin{array}{c}\text { Chronic hepatitis C patients } \\
(\mathrm{n}=23)\end{array}$ \\
\hline ALT(U/L) mean $\pm \mathrm{SD}$ & $67,27 \pm 151,16$ & $210,43 \pm 559.75$ \\
\hline AST $(\mathrm{U} / \mathrm{L})$ mean $\pm \mathrm{SD}$ & $37,59 \pm 49,27$ & $192,47 \pm 574.43$ \\
\hline ALP $(\mathrm{U} / \mathrm{L})$ mean $\pm \mathrm{SD}$ & $82,18 \pm 33.65$ & $96,95 \pm 34.44$ \\
\hline $\mathrm{LDH}(\mathrm{U} / \mathrm{L})$ mean $\pm \mathrm{SD}$ & $186,04 \pm 54.4$ & $351,26 \pm 483.98$ \\
\hline $\mathrm{gGT}(\mathrm{U} / \mathrm{L})$ mean $\pm \mathrm{SD}$ & $27,54 \pm 36$ & $77,60 \pm 80.32$ \\
\hline Bilirubin total $(\mu \mathrm{mol} / \mathrm{l})$ mean $\pm \mathrm{SD}$ & $11,22 \pm 5.66$ & $13,83 \pm 22.44$ \\
\hline Bilirubin direct $(\mu \mathrm{mol} / \mathrm{l})$ mean $\pm \mathrm{SD}$ & $5,47 \pm 3.9$ & $6,87 \pm 16.12$ \\
\hline Albumin $(\mathrm{g} / \mathrm{l})$ mean $\pm \mathrm{SD}$ & $42,15 \pm 4.48$ & $41,45 \pm 3.52$ \\
\hline Platelets $\left(\mathrm{x} 10^{9} / \mathrm{l}\right) \mathrm{mean} \pm \mathrm{SD}$ & $235,76 \pm 80$ & $214,52 \pm 75.36$ \\
\hline Cholesterol $(\mathrm{mmol} / \mathrm{l})$ mean $\pm \mathrm{SD}$ & $4,51 \pm 1.17$ & $4,55 \pm 1$ \\
\hline Triglycerides $(\mathrm{mmol} / \mathrm{l})$ mean $\pm \mathrm{SD}$ & $1,20 \pm 0.44$ & $1,8 \pm 0.66$ \\
\hline HDL-cholesterol $(\mathrm{mmol} / \mathrm{l}) \mathrm{mean} \pm \mathrm{SD}$ & $1,12 \pm 0.29$ & $0,9 \pm 0.23$ \\
\hline
\end{tabular}




\begin{tabular}{|l|c|c|}
\hline LDL-cholesterol $(\mathrm{mmol} / \mathrm{l})$ mean $\pm \mathrm{SD}$ & $2,81 \pm 1.12$ & $2,87 \pm 0.94$ \\
\hline Haemoglobin $(\mathrm{g} / \mathrm{dl})$ mean $\pm \mathrm{SD}$ & $138,57 \pm 17.92$ & $141,60 \pm 18.95$ \\
\hline Glucose $(\mathrm{mmol} / \mathrm{l})$ mean $\pm \mathrm{SD}$ & $5,76 \pm 1.64$ & $6,02 \pm 2.19$ \\
\hline Uric acid $(\mu \mathrm{mol} / \mathrm{l})$ mean $\pm \mathrm{SD}$ & $294,81 \pm 81.65$ & $343,43 \pm 66.93$ \\
\hline Vitamin D $(\mathrm{ng} / \mathrm{mL})$ mean $\pm \mathrm{SD}$ & $14,85 \pm 8.1$ & $21,9 \pm 13.43$ \\
\hline$<30 \mathrm{ng} / \mathrm{ml}$ serum $25-$ HidroxyVitamin D & $20(91 \%)$ & $18(78 \%)$ \\
\hline$\geq 30 \mathrm{ng} / \mathrm{ml}$ serum $25-$ HidroxyVitamin D & $2(9 \%)$ & $5(22 \%)$ \\
\hline
\end{tabular}

\section{DISCUSSION}

Over the past decade, numerous studies reported that patients with chronic liver disease, especially HCVpositive and HBV-positive patients, have decreased $25(\mathrm{OH}) \mathrm{D}$ levels compared to healthy people $[5,6,7]$.

Our study was performed during the 6 mounts in the year 2018, the period of increased sunlight exposure, and we know that the Vitamin D levels are higher in this period.

This study confirms that Vitamin D insufficiency is very common in Macedonian healthy people and patients with chronic hepatitis B and C.

We established that serum Vitamin D levels are lower in healthy women, and women with hepatitis B and C compared with males, but this difference may be explained, in part, by older age of women included in the study as age is inversely correlated with $25(\mathrm{OH}) \mathrm{D}$ serum levels. These results confirmed the data from the study of Ladero [8].

We found that Vitamin D is significantly lower in patients with hepatitis B compared to the control group, but there is not a significant correlation between these two groups. Statistical analysis showed that patients with chronic hepatitis $\mathrm{C}$ had statistically higher Vitamin D levels than patients with chronic hepatitis B with significant correlation $\mathrm{p}=0,04$. Therefore, we can clearly state that HBV- infected patients are at high risk of Vitamin D deficiency.

In this study, deficiency and severe Vitamin D deficiency were observed more frequently in patients with HBVrelated liver disease, and we found that $91 \%$ of patients with chronic hepatitis B had Vitamin D deficiency (Vitamin D < $30 \mathrm{ng} / \mathrm{ml}$ ). These results confirmed the data of Hoan [9].

We found that HBsAg and HBeAg serum levels in patients with hepatitis B were not associated with $25(\mathrm{OH}) \mathrm{D}$ serum levels, but Farnik et al. found that there is a significant association between low serum concentrations of $25(\mathrm{OH}) \mathrm{D} 3$ and higher levels of HBV replications in chronically infected patients [1].

A large number of studies have examined the relationship between the Vitamin D status of patients with chronic hepatitis $\mathrm{C}$ and disease outcome. The majority found that HCV-positive patients have depressed 25(OH)D levels. We found out that $78 \%$ of the HCV-positive patients had $25(\mathrm{OH}) \mathrm{D}$ levels below $30 \mathrm{ng} / \mathrm{ml}$. It is possible that $\mathrm{HCV}$ depresses $25(\mathrm{OH}) \mathrm{D}$ levels by altering lipid metabolism. A recent study has shown that $\mathrm{HCV}$ reduces production of 7-dehydrocholesterol, the precursor of endogenously-produced Vitamin D. Most studies indicate that the severity of Vitamin D deficiency correlates with the severity of liver dis- ease [10] and high prevalence of Vitamin D deficiency $(>90 \%)$ in chronic liver disease has been reported to be associated with liver disease progression [11].

$\mathrm{HCV}$ infection is associated with intrahepatic inflammation and enhanced circulating levels of multiple inflammatory cytokines including members of the TNF superfamily. Vitamin D inhibits inflammatory T cell responses, reducing the production of IFNã and IL-17 in favor of IL-4 and IL10. These findings suggest that Vitamin D deficiency is likely to exacerbate chronic inflammation in $\mathrm{HCV}$-positive patients [10].

We didn't found relationships between Vitamin D and other routine biochemical and hematological parameters which are in accordance with other studies [8].

There is increasing evidence of Vitamin D deficiency effects on a wide spectrum of diseases, including osteoporosis, autoimmunity, asthma, infectious diseases, several forms of malignancy and even psychiatric disorders $[12,13]$. Also, many studies have shown that Vitamin D analogues inhibit the proliferation of malignant cells, and they have demonstrated that hepatoma cells are sensitive to $1,25(\mathrm{OH})_{2} \mathrm{D}$ [4].

\section{CONCLUSION}

In our study, we proved that Macedonian population suffers from a deficiency of vitamin D. This was confirmed with the finding that only $12 \%$ of all subjects $(n=145)$ had values of vitamin $\mathrm{D}$ within normal limits. This indicates the need to consume foods rich in Vitamin D, require higher sun exposure or vitamin D supplementation should be recommended in healthy people, patients with chronic hepatitis $\mathrm{C}$ and $\mathrm{B}$.

In the meantime, to preserve bone, serum $25(\mathrm{OH}) \mathrm{D}$ levels should be checked in HBV, and HCV positive patients and patients with Vitamin D deficiency should be treated with appropriate doses of Vitamin D and calcium supplements.

The possible causal relationship between vitamin D metabolism and HBV replication, which should be proven by future studies, may offer attractive therapeutic opportunities for the treatment of chronic hepatitis B.

We need further investigations in our population to examine Vitamin D blood concentration in other cities of the Republic of Macedonia and to examine the reason for this massive deficit of vitamin D.

\section{ACKNOWLEDGMENTS}

This research is co-funded by the Farmahem diagnostics Macedonia. 
REFERENCES:

1. Zhu H, Liu X, Ding Y, Zhou H, Wang Y, Zhou Z, et al. Relationships between low serum vitamin D levels and HBV "a" determinant mutations in chronic hepatitis B patients. J Infect Dev Ctries. 2016 Sep 30;10(9):10251030. [PubMed] [Crossref]

2. Villar L, Campo J, Ranchal I, Lampe E, Gomez E. Association between Vitamin D and hepatitis $\mathrm{C}$ virus infection: A meta-analysis. World $J$ Gastroenterol. 2013 Sep 21;19(35): 5917-24.[PubMed] [CrossRef]

3. Zhang R, Naughton DP. Vitamin $\mathrm{D}$ in health and disease: Current perspectives.Nutr J. 2010 Dec; 8;9:65. [PubMed] [Crossref]

4. Gutierrez JA, Parikh N, Branch AD. Classical and emerging roles of vitamin D in hepatitis C virus infection. Semin Liver Dis. 2011 Nov;31(4): 387-98. [PubMed] [Crossref]

5. Farnik H, Bojunga J, Berger A, Allwinn R, Waidmann O, Kronen- berger B, et al. Low Vitamin D serum concentration is associated with high levels of hepatitis B virus replication in chronically infected patients. Hepatology.2013;58:1270-1276. [PubMed] [Crossref]

6. Gerova DI, Galunska BT, Ivanova II, Kotzev IA, Tchervenkov TG, Balev SP, et al. Prevalence of Vitamin D deficiency and insufficiency in Bulgarian patients with chronic Hepatitis C viral infection. Scand J Clin Lab Invest. 2014; 74 : 665-672. [PubMed] [Crossref]

7. Wong GL, Chan HL, Chan HY, Tse CH, Chim AM, Lo AO, et al. Adverse effects of Vitamin D deficiency on outcomes of patients with chronic hepatitis B. Clin Gastroenterol Hepatol. 2014 Apr;13(4):783-790. [PubMed] [Crossref]

8. Ladero JM, Torrejón MJ, Sanchez-Pobre P, Suarez A, Cuenca F, de la Orden V, et al. Vitamin D defi- ciency and vitamin D therapy in chronic hepatitis C. Ann Hepatol. 2013 Mar-Apr;12(2):199-204. [PubMed]

9. Hoan NX, Khuyen N, Binh MT, Giang DP, Van Tong H, Hoan PQ, et al. Association of vitamin $D$ deficiency with hepatitis B virus - related liver diseases. BMC Infect Dis. 2016 Sep 23;16(1):507. [PubMed] [Crossref]

10. Rahman AH, Branch AD. Vitamin D for your patients with chronic hepatitis C? J Hepatol. 2013 Jan; 58(1):184-189. [Crossref]

11. Arteh J, Narra S, Nair S. Prevalence of Vitamin D deficiency in chronic liver disease. Dig Dis Sci. 2010 Sep;55(9):2624-8. [PubMed] [Crossref]

12. Holick MF. Vitamin D deficiency. N Engl J Med. 2007 Jul; 357(3):266-81. [PubMed] [Crossref]

13. Rosen CJ. Clinical practice. Vitamin D insufficiency. $N$ Engl J Med. 2011 Jan;364(3):248-54. [PubMed] [Crossref]

Please cite this article as: Ilkovska B, Trifunova BK, Sandra Hristovska S, Ivanovska M. Vitamin D levels in patients with chronic hepatitis B, chronic hepatitis C, and health controls. J of IMAB. 2019 Apr-Jun;25(2):2553-2558.

DOI: https://doi.org/10.5272/jimab.2019252.2553

Received: 20/11/2018; Published online: 28/05/2019

\author{
Address for correspondence: \\ Biljana Ilkovska \\ Department of Medical biochemistry PHO Clinical Hospital dr. Trifun Panovski \\ st. Partizanska b.b, 7000 Bitola, R. Macedonia \\ Tel: +389-71-361-262 \\ Email: drbiljanailkovska@yahoo.com
}

